
державний університет залізничного транспорту)

\title{
Забезпечення технологічної надійності роботи підрозділів ремонтного господарства локомотивного депо
}

Розглянуто питання забезпечення технологічної надійності роботи ремонтних підрозділів локомотивного депо з ремонту швидкісного рухомого складу за критерієм оптимальної кількості виконавців у ремонтних бригадах, щзо забезпечить виконання ТО, ПР для приписного парку локомотивів, у тому числі з інших локомотивних депо. Визначено залежності зміни ймовірності обслуговування заявки на ремонт від інтенсивності потоку заявок на ремонт, а також оптимальну кількість виконавців у ремонтних бригадах.

Ключові слова: імовірність обслуговування, параметр потоку заявок на ремонт.

\section{Постановка проблеми}

Розпорядженням Кабінету Міністрів України N 979-р від 31 грудня 2004 року [1] було схвалено Концепцію Державної цільової програми впровадження на залізницях швидкісного руху пасажирських поїздів на 2005-2015 рр. (далі Програма). Цією концепцією, зокрема, визначалися основні етапи впровадження на залізницях швидкісного руху пасажирських поїздів на 2005-2015 pp., в тому числі проведення якісного і своєчасного технічного обслуговування та ремонту швидкісного тягового рухомого складу, планувалося будівництво поблизу м. Києва окремого локомотивного депо для обслуговування електровозів типу ДС3 і ДС4 та поїздів з примусовим нахилом кузова у кривих. Також було заплановано будівництво пунктів технічного обслуговування швидкісного тягового рухомого складу на базі локомотивних депо Львів-Захід, ОдесаЗастава, Полтава, Харків - Головне (або моторвагонного депо Харків), а також на Донецькому залізничному вузлі. Швидкісний рух пасажирських поїздів у нашій країні впроваджено, курсують поїзди $з$ високотехнологічним обладнанням, яке потребує сучасного підходу до його технічного обслуговування. Однак намічені Програмою кроки реалізовані частково, а необхідність у їх виконанні залишається не лише актуальною, але й потребує розширення заходів 3 їх реалізації. Насамперед, це пов’язано з необхідністю забезпечення обслуговуванням і ремонтом рухомого складу не лише приписного парку, а і іншого РС, який на цей час потребує проведення ТО, ПР. Для реалізації цих завдань ремонтному підприємству необхідно мати резервні виробничі потужності і резервні ремонтні бригади.

(C) С. С. Яковлев, 2019

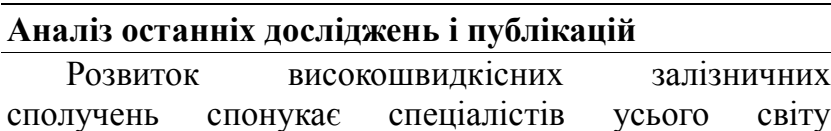
досліджувати цей напрям 3 усіх точок зору. Так, в дослідженні [2] розглядаються проблеми, 3 якими зіткнулася Німеччина 3 появою великої кількості приватних операторів, які працюють на лініях, розташованих по великих територіях. Це призвело до створення нової інфраструктури технічного обслуговування невеликих парків рухомого складу, тобто до збільшення кількості депо 3 відповідним зниженням питомої кількості одиниць рухомого складу, що припадають на одне ремонтне підприємство. S. Baumann, H.-W. Keßler [3] у зв' язку з посиленням конкуренції на залізничному транспорті бачать як 3 одну 3 основних вимог - підвищення експлуатаційної готовності рухомого складу, яке може бути досягнуто за рахунок скорочення простоїв в депо i прискореного усунення несправностей шляхом підвищення якості організації поточного утримання тягового рухомого складу, підвищення якості виконання планових ремонтних робіт, підвищення якості робіт при усуненні несправностей і т. ін. В дослідженнях вітчизняних фахівців приділена увага оптимізації системи ремонту рухомого складу [4 - 8] на основі різних підходів до формування системи утримання різних одиниць рухомого складу за життєвий цикл.

Виділення невирішених частин загальної проблеми

Багато задач, що виникають при розвитку високошвидкісного руху, вирішуються на основі попереднього досвіду експлуатації рухомого складу. Разом $з$ цим ряд задач неможливо вважати вирішеними остаточно без їх наукового обгрунтування. Необхідно залучити до їх вирішення як апробовані методи $[9,10$, $11,13]$, так і методи, що набули розвитку в суміжних галузях $[12,14,15,16]$. 


\begin{tabular}{l} 
Мета дослідження \\
\hline Метою статті $є$ проведення дослідження оцінки \\
надійності роботи ремонтних підрозділів \\
локомотивного депо з ремонту швидкісного рухомого \\
складу за критерієм оптимальної кількості ремонтних \\
бригад для забезпечення виконання ТО, ПР \\
приписного парку локомотивів, а також локомотивів 3 \\
інших локомотивних депо; визначення залежностей \\
зміни ймовірності обслуговування заявки на ремонт \\
від інтенсивності потоку заявок на ремонт, а також \\
визначення оптимальної кількості ремонтних бригад.
\end{tabular}

\section{Викладення основного матеріалу дослідження}

На ефективність роботи сучасного ремонтного виробництва впливає нестабільність обсягів виконуваних робіт. Це негативно позначається як на використанні трудових ресурсів, так i якості ремонтних робіт. 3 математичної точки зору, ремонтне господарство можна розглядати як систему масового обслуговування (СМО) 3 регламентованим часом перебування заявки (ремонтованої секції тепловоза, вузла, деталі) в системі, 3 упорядкованим обслуговуванням, на вхід якої подається найпростіший потік заявок А $з$ інтенсивністю $\lambda$. На виході з системи утворюються два потоки: $\bar{L}$ - заявки, що обслужені з інтенсивністю $\lambda_{0}$, та $C$ - заявки, що не обслужені з інтенсивністю $\lambda_{H}$.

Математичне очікування часу обслуговування локомотивів визначається за формулою

$$
\bar{t}_{\text {обс }}=\frac{\sum_{i=1}^{K} t_{\text {обсi }} n_{p i}}{\sum_{i=1}^{K} n_{p i}} .
$$

Інтенсивність обслуговування $є$ величиною, що обернена середньому часу обслуговування заявки, тобто

$$
\mu=\frac{1}{\bar{t}_{\text {обс }}}=\frac{\sum_{i=1}^{K} n_{p i}}{\sum_{i=1}^{K} t_{\text {обс }} n_{p i}}
$$

Параметр інтенсивності очікування є величиною, що обернена середній тривалості очікування обслуговування, і визначається за формулою

$$
v=-\frac{1}{t_{\text {ож }}}=\frac{\sum_{i=1}^{K} m_{p i}}{\sum_{i=1}^{K} t_{\text {ож }} m_{p i}}
$$

де $m_{p i}$ - число очікувань обслуговування, що спостерігалися на обраному інтервалі.

Якщо до моменту надходження заявки в систему (ремонтну дільницю) хоча 6 один $3 \quad \delta$-виконавців вільний, то ця заявка приймається до обслуговування тільки одним (будь-яким) з вільних виконавців. Якщо до моменту надходження заявки в систему всі виконавці зайняті, то дана заявка залишиться не обслуженою. На зайнятого виконавця діє пуассонівський потік з інтенсивністю

$\mu^{x}=\mu+v$

де величина $\mathcal{V}$ характеризує інтенсивність виходу заявок з системи, не чекаючи кінця обслуговування.

У будь-який момент часу $t$ система ремонтного забезпечення може перебувати в одному 3 таких станів:

$X_{0}$ - в системі немає жодної заявки (вільні всі виконавці);

$X_{1}$ - в системі знаходиться одна заявка і вона обслуговується одним (будь-яким) з $\delta$-виконавців;

$X_{K}$ - в системі знаходиться $K$ заявок, причому $1<K<\delta_{i}$, усі вони обслуговуються (кожна заявка одним виконавцем);

$X_{\delta}-$ в системі знаходиться така кількість заявок $K$, яка дорівнює $\delta$-виконавцям;

$X_{\delta+j}$ - в системі знаходиться $\delta+j$ заявок, причому $\delta$ заявок обслуговуються $\delta$-виконавцями, а $j$ заявок очікують обслуговування.

Для оцінки стану зайнятої ремонтної дільниці запишемо таку систему диференціальних рівнянь:

при $K=0: \frac{d P_{0}(t)}{d t}=-\lambda P_{0}(t)+(\mu+v) P_{1}(t)$, 
при $K=1: \frac{d P_{1}(t)}{d t}=-(\lambda+\mu+v) P_{1}(t)+\lambda P_{0}(t)+2(\mu+v) P_{2}(t)$,

при $1<K<\delta: \frac{d P_{K}(t)}{d t}=-[\lambda+K(\mu+v)] P_{K}(t)+\lambda P_{K-1}(t)+(K+1)(\mu+v) P_{K+1}(t)$,

при $K=\delta: \frac{d P_{\delta}(t)}{d t}=-[\lambda+\delta(\mu+v)] P_{\delta}(t)+\lambda P_{\delta-1}(t)+\left[\delta_{\mu}+v\left(\delta+\frac{\mu}{v}+1\right)\right] P_{\delta+1}(t)$,

при $K=\delta+j$ :

$\frac{d P_{\delta+j}(t)}{d t}=-[\lambda+(\delta+j) \mu+(\delta+j) v] P_{\delta+j}(t)+\lambda P_{\delta+j-1}(t)+[\delta(\mu+1)+j \mu(\delta+j+1) v] P_{\delta+j+1}(t)$.

Для розв'язання систем диференційних рівнянь приймаємо такі початкові умови:

$$
\sum_{K=0}^{\delta} P_{K}(t)=1
$$

$$
P_{0}(0)=1 ; \quad P_{K}(0)=0 ; \quad K=1,2,3 \ldots \delta .
$$

При цьому у початковий момент часу при $t=0$ система вільна $\mathrm{i}$ для будь-якого моменту часу $t$

В умовах стаціонарного режиму роботи при $t \rightarrow \infty$ система диференційних рівнянь перетворюється на систему алгебраїчних рівнянь: виконується умова

$$
\left.\begin{array}{l}
-\lambda P_{0}(t)+(\mu+v) P_{i}(t)=0 \\
-(\lambda+\mu+v) P_{i}(t)+\lambda P_{0}(t)+2(\mu+v) P_{2}(t)=0 \\
-[\lambda+K(\mu+v)] P_{K}+\lambda P_{K-1}(t)+(K+1)(\mu+v) P_{K+1}(t)=0 \\
-[\lambda+\delta(\mu+v)] P_{\delta}(t)+\lambda P_{\delta-1}(t)+\left[\delta \mu+\left(\delta+\frac{\mu}{v}+1\right)\right] P_{\delta+1}(t)=0 ; \\
-[\lambda+(\delta+j) \mu+(\delta+j) v] P_{\delta+j}(t)+\lambda P_{\delta+j-1}(t)+[\delta(\mu+1)+j \mu+(\delta+j+1) v] P_{\delta+j+1}(t)=0 .
\end{array}\right\}
$$

3 розв'язанням цієї системи рівнянь можна отримати значення імовірності стану в загальному вигляді, що визначається за формулою

$$
P_{K}=\frac{1}{K !}\left(\frac{\lambda}{\mu+v}\right)^{K} P_{0} \text { при } K=0,1,2 \ldots \delta,
$$

де $P_{K}$ - ймовірність того, що в системі зайняті всі $\delta$ виконавці, тобто $K=\delta$;

$P_{0}$ - ймовірність того, що в системі вільні всі $\delta$ виконавці, тобто $K=0$.

Позначивши $\frac{\lambda}{\mu}$ через $\rho$, отримуємо вираз

$$
P_{K}=\frac{1}{K !}\left(\frac{\rho}{1+\frac{\nu}{\mu}}\right)^{K} P_{0} \text { при } K=\delta \text {. }
$$

Імовірність того, що обслуговуванням заявок зайняті всі $\delta$-виконавці і $j$ заявок очікують обслуговування, дорівнює

$$
P_{\delta+1}=\frac{1}{\delta ! \delta^{j}}\left(\frac{\rho}{1+\frac{\nu}{\mu}}\right)^{K} P_{0} \quad \text { при } K=\delta+j .
$$


Імовірність відсутності заявок в системі, тобто коли все $\delta$ - виконавці вільні, встановлюється 3 нормуючої умови (10).

Імовірність того, що всі $\boldsymbol{\delta}$-виконавці вільні, дорівнює

$$
P_{0}=\frac{1}{\sum_{K=0}^{\delta} \frac{1}{K !}\left(\frac{\rho}{1+\frac{v}{\mu}}\right)^{K}+\frac{1}{\delta !}\left(\frac{\rho}{1+\frac{v}{\mu}}\right)^{j} \sum_{1}^{j}\left[\frac{\rho}{\delta\left(1+\frac{v}{\mu}\right)}\right]^{j}} .
$$

Імовірність того, що заявка отримає відмову, дорівнює

$P_{\text {відм. }}=\frac{\left(\frac{\rho}{1+\frac{\nu}{\mu}}\right)^{\delta+j}}{\delta ! \delta^{j}} P_{0}$.

Ймовірність обслуговування заявки дорівнює

$P_{\text {обс. }}=1-P_{\text {отк. }}=1-\frac{\left(\frac{\rho}{1+\frac{\nu}{\mu}}\right)^{\delta+j}}{\delta ! \delta^{j}} \quad P_{0}$.

При коливанні потоку заявок на ремонт і часу на організацію ремонту для підвищення ефективності роботи ремонтних підрозділів можна використовувати два шляхи: взаємодопомогу, яка можлива за умови взаємозамінності виконавців, або створення резервної бригади 3 кількох виконавців. На підставі цього проведено розрахунки зміни кількості виконавців $\delta$, що проводять ТО, ПР, в залежності від інтенсивності вхідного потоку $\lambda$ при однаковому значенні кількості заявок $K$. Як видно 3 розрахункових даних, що наведені в табл. 1, і залежностей, які подано на рис. 1, 2 , найбільш прийнятним $\epsilon$ створення резервної бригади. Варіюючи чисельністю виконавців у бригаді, можна визначити діапазон найбільшої імовірності обслуговування заявки (закінчення ремонтних робіт). Оптимальне число виконавців резервної бригади можна встановити, мінімізуючи приведені витрати на ремонт однієї секції локомотива на основі цільової функції оцінки технологічної надійності ремонтної системи, що визначається за формулою
$\theta=C_{p} \frac{\delta_{p}}{N}+a_{p} T_{c p}$,

де $C_{p}$ - заробітна плата одного виконавця із резервної бригади, грн/люд, $C_{p}=5642$ грн;

$\delta_{p}$ - число виконавців в резервній бригаді, осіб, $\delta_{p}=4 \div 10$

$N$ - програма ремонту за відповідний період, секцій,

$$
N=\left\{N_{\delta_{p}}\right\}=N_{\delta_{p}}=10 \div 50 ;
$$

$a_{p}$ - розрахункова вартість 1 год простою секції локомотива в ремонті, грн/люд;

$T_{c p}$ - середній час перебування локомотива в ремонті, год. 


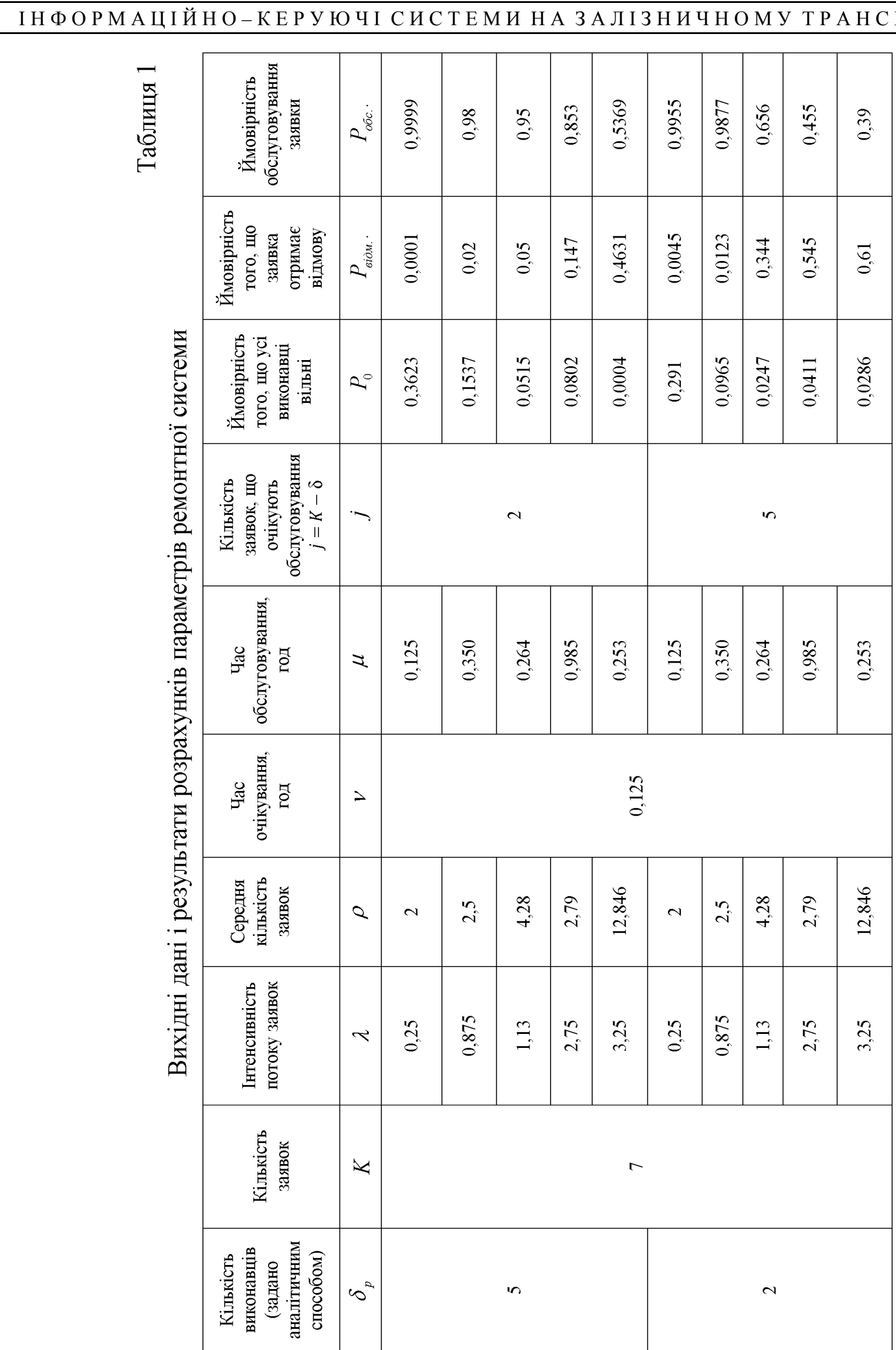




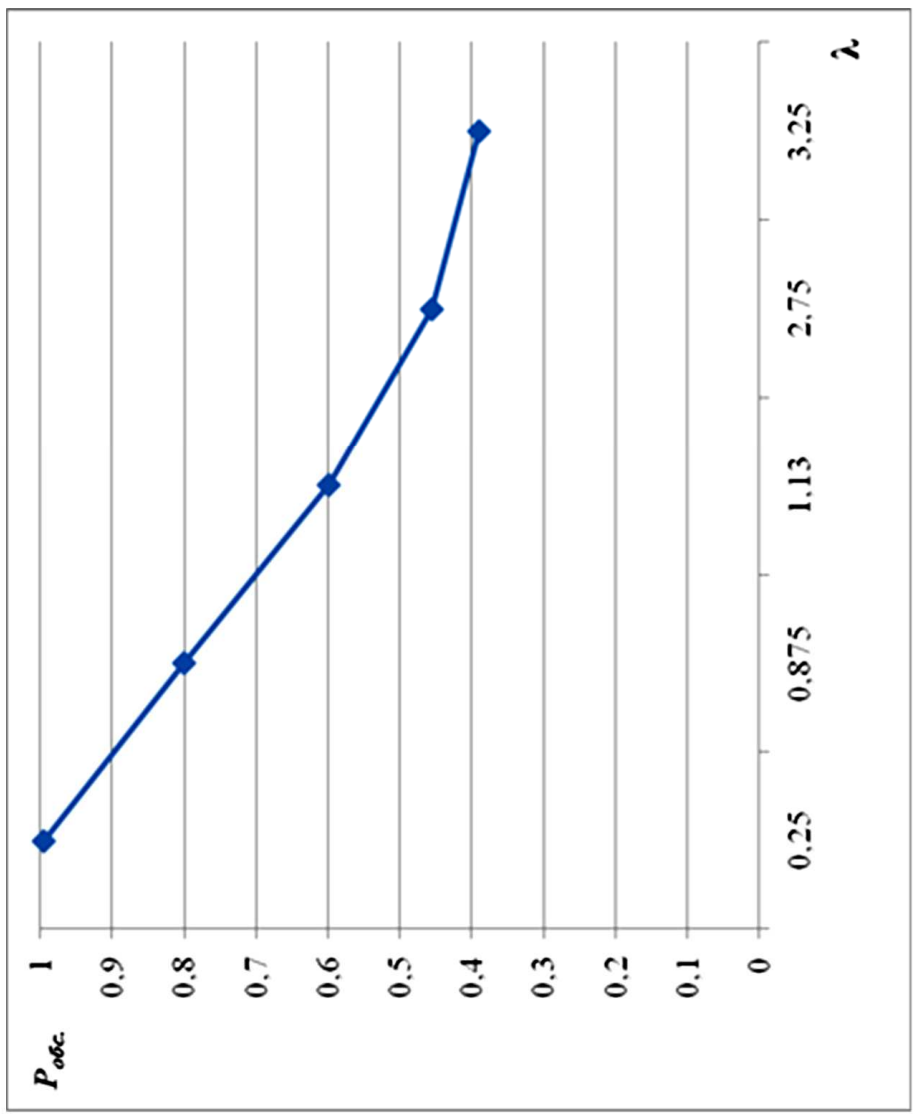

.

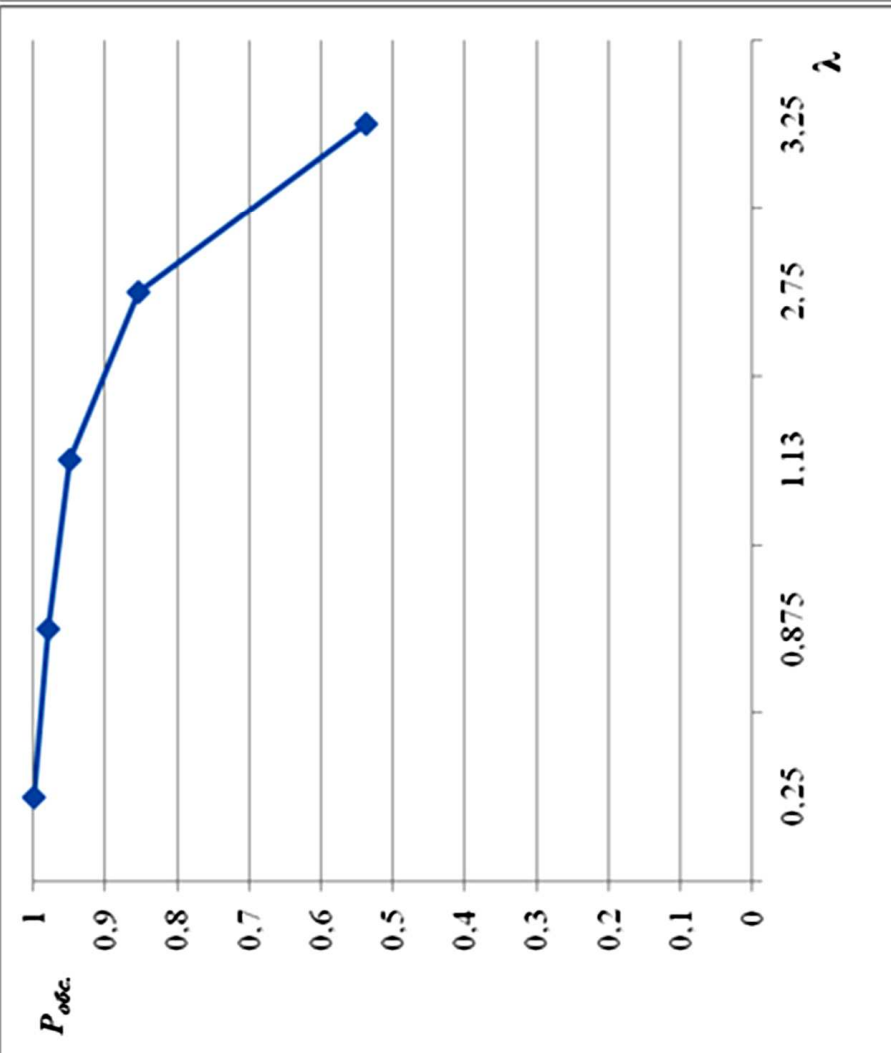

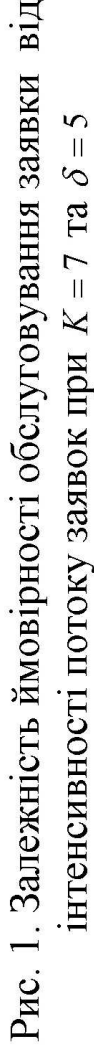


Середній час перебування локомотива в ремонті визначимо за формулою

$$
T_{c p}=\left(R+t_{3}\right) m_{l}
$$

де $m_{л}$ - число позицій на ремонтній лінії;

$R$ - час простою локомотива в ремонті на одній позиції, год;

$t_{3}$ - середній час затримки локомотива в ремонті для виконання необхідного обсягу робіт, год,

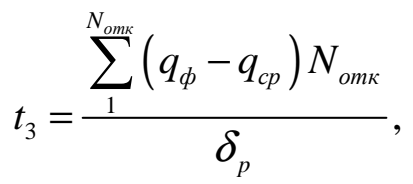

де $q_{\phi}$ - фактична трудоємність ремонту локомотивів, люд.год;

$q_{c p}$ - середня трудоємкість, люд.год;

$N_{\text {отк }}$ - число секцій, які отримали відмову в обслуговуванні на ремонтній лінії, секції, $N_{\text {omк }}=2 \div 5$.

Таким чином, цільову функцію можна подати як

$\theta=C_{p} \frac{\delta_{p}}{N}+\alpha_{p}\left[m_{l} R+\frac{\sum_{1}^{N_{o m \kappa}}\left(q_{\phi}-q_{c p}\right) N_{o m \kappa}}{\delta_{p}}\right]$

Розв'язуючи рівняння (21) при різній кількості виконавців $\delta_{p}$, можна визначити необхідну кількість виконавців у резервній бригаді, що забезпечить мінімальні витрати на ремонт.

Розрахунок значень $t_{3}$ в залежності від кількості виконавців в ремонтній бригаді $\delta_{p}$ наведено в табл. 2 . 3 урахуванням цих розрахунків в табл. 3 подано розрахунки $T_{c p}$.

За наведеними в табл. 3 даними на рис. 3 подано динаміку зміни середнього часу в ремонті при різних значеннях числа позицій на ремонтній лінії $m_{n}$. Зі зростанням кількості виконавців в ремонтній бригаді $\delta_{p}$, незалежно від величини $m_{л}$ спостерігається зменшення середнього часу простою в ремонті $T_{c p}$.
Причому інтенсивність зменшення $T_{c p}$ найбільша при невеликих значеннях $m_{л}$. Тобто при збільшенні кількості виконавців $\delta_{p}$ вдається значно скоротити час простою в ремонті. Слід відмітити, що зі зростанням величини $\delta_{p}$ середній час простою в ремонті $T_{c p}$ майже не відрізняється, що може здаватися основним фактором, який впливає на величину $T_{c p}$.

Разом $з$ цим, при зростанні $\delta_{p}$ ростуть витрати на утримання ремонтних бригад, що добре видно з даних, наведених у табл. 4, 5 .

Ці розрахунки реалізовані у вигляді графічних залежностей, що наведені на рис. 4, i мають дві складові, які зі зростанням $\delta_{p}$ зростають, а інші зі зростанням $\delta_{p}$ зменшуються.

Таблиця 2

Розрахунок середнього часу затримки локомотивів у ремонті, $t_{3}$

\begin{tabular}{|c|c|c|c|c|}
\hline $\begin{array}{c}q_{\phi}, \\
\text { осіб. год }\end{array}$ & $\begin{array}{c}q_{c p}, \\
\text { осіб. год }\end{array}$ & $\begin{array}{c}N_{\text {отк }}, \\
\text { Шт. }\end{array}$ & $\begin{array}{r}\delta_{p}, \\
\text { осіб } \\
\end{array}$ & $\begin{array}{r}t_{3}, \\
\text { год }\end{array}$ \\
\hline \multirow{2}{*}{8,65} & \multirow{9}{*}{8,65} & \multirow{9}{*}{4} & 1 & 24,14 \\
\hline & & & 2 & 12,07 \\
\hline \multirow{2}{*}{$\begin{array}{c}9,93 \\
(8,65+15 \%)\end{array}$} & & & 3 & 8,5 \\
\hline & & & 4 & 6,21 \\
\hline \multirow{2}{*}{$\begin{array}{c}10,81 \\
(8,65+25 \%)\end{array}$} & & & 5 & 4,828 \\
\hline & & & 6 & 4,02 \\
\hline $\begin{array}{c}11,245 \\
(8,65+30 \%)\end{array}$ & & & 7 & 3,45 \\
\hline & & & 8 & 3,02 \\
\hline $\begin{array}{c}11,68 \\
(8,65+35 \%)\end{array}$ & & & 9 & 2,69 \\
\hline
\end{tabular}




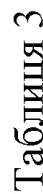

\begin{tabular}{|c|c|c|c|c|c|c|c|c|c|}
\hline 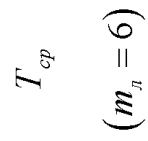 & $\begin{array}{l}1 \\
\infty \\
\infty \\
\infty\end{array}$ & $\frac{\stackrel{N}{\sigma}}{\underset{\infty}{\infty}}$ & $\hat{6}$ & $\begin{array}{l}\stackrel{0}{2} \\
\text { an } \\
\text { f }\end{array}$ & $\begin{array}{l}\infty \\
0 \\
2 \\
0 \\
q\end{array}$ & $\frac{N}{n^{n}}$ & $\hat{n}$ & $\frac{1}{0}$ & $\begin{array}{l}J \\
\infty \\
\infty \\
\sim\end{array}$ \\
\hline $\begin{array}{l}\pi \\
0 \quad \\
\equiv\end{array}$ & $\hat{0}$ & ñ & $\begin{array}{l}n \\
\tilde{n} \\
n\end{array}$ & $\frac{n}{\sigma}$ & $\frac{\Xi}{\Xi^{n}}$ & $\overrightarrow{\rho^{n}}$ & $\begin{array}{l}n \\
n \\
i \\
\text { ñ }\end{array}$ & $\vec{n}$ & 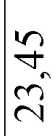 \\
\hline $\begin{array}{l}\mathcal{J} \\
\| \\
\Xi\end{array}$ & 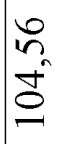 & $\begin{array}{l}\infty \\
\text { Nh } \\
\infty \\
n\end{array}$ & $\stackrel{\sim}{\sim}$ & $\begin{array}{l}\overrightarrow{1} \\
\infty \\
m\end{array}$ & $\begin{array}{l}\frac{N}{m} \\
\stackrel{n}{N}\end{array}$ & $\begin{array}{l}\infty \\
0 \\
\vdots \\
d\end{array}$ & $\frac{\infty}{i}$ & 舟 & $\begin{array}{l}0 \\
\infty \\
\infty\end{array}$ \\
\hline $\begin{array}{l}\pi \\
\pi \\
\equiv\end{array}$ & $\frac{N}{\sigma}$ & $\begin{array}{l}\bar{\gamma} \\
\text { d }\end{array}$ & $\frac{n}{n}$ & $\begin{array}{l}\mathfrak{b} \\
\dot{N}\end{array}$ & 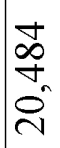 & $\begin{array}{l}\varrho \\
\infty\end{array}$ & $\begin{array}{l}n \\
n \\
0 \\
0\end{array}$ & $\begin{array}{l}0 \\
0 \\
n\end{array}$ & S \\
\hline 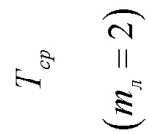 & $\begin{array}{l}\infty \\
\text { N } \\
\text { nn } \\
n\end{array}$ & $\stackrel{\Xi}{ \pm}$ & $\bar{\sim}$ & $\begin{array}{l}\stackrel{1}{f} \\
\underset{6}{0}\end{array}$ & $\begin{array}{l}0 \\
2 \\
6 \\
2\end{array}$ & $\begin{array}{l}\mathbb{J} \\
\text { I }\end{array}$ & $\hat{\hat{\theta}}$ & $\mathbb{O}_{0}$ & $\begin{array}{l}\infty \\
2 \\
a\end{array}$ \\
\hline$\Xi^{\sigma}$ & & & & & $\begin{array}{l}0 \\
\cdots \\
\sim\end{array}$ & & & & \\
\hline $\begin{array}{l}\stackrel{s}{ \pm} \\
\pm \\
\pm\end{array}$ & $\begin{array}{l} \pm \\
\stackrel{\Xi}{0}\end{array}$ & $\begin{array}{l}\mathbf{0} \\
\pm\end{array}$ & $\stackrel{n}{o}$ & $\begin{array}{c}\bar{N} \\
\infty\end{array}$ & $\begin{array}{l}\infty \\
\text { N. } \\
\infty \\
0\end{array}$ & $\begin{array}{l}\delta \\
0 \\
6\end{array}$ & $\begin{array}{l}n \\
i n \\
i n\end{array}$ & $\begin{array}{l}\delta \\
0 \\
n\end{array}$ & $\begin{array}{l}\hat{\sigma} \\
\sigma\end{array}$ \\
\hline$N^{3}$ & $\frac{\Xi}{\Xi^{n}}$ & $\begin{array}{l}1 \\
\text { in }\end{array}$ & $n^{n}$ & $\widetilde{\sim}^{\widetilde{6}}$ & \begin{tabular}{l}
$\infty$ \\
\multirow{1}{*}{} \\
$\infty$ \\
$\nabla$
\end{tabular} & $\frac{\delta}{\delta}$ & $\begin{array}{l}\stackrel{n}{\partial} \\
m\end{array}$ & $\begin{array}{c}\delta \\
0 \\
m\end{array}$ & $\begin{array}{l}8 \\
\text { in }\end{array}$ \\
\hline $10^{2}$ & - & $\sim$ & $m$ & $\nabla$ & in & 0 & $r$ & $\infty$ & $a$ \\
\hline$\approx$ & & & & & $N$ & & & & \\
\hline
\end{tabular}

5
5
5
\pm
11
0 


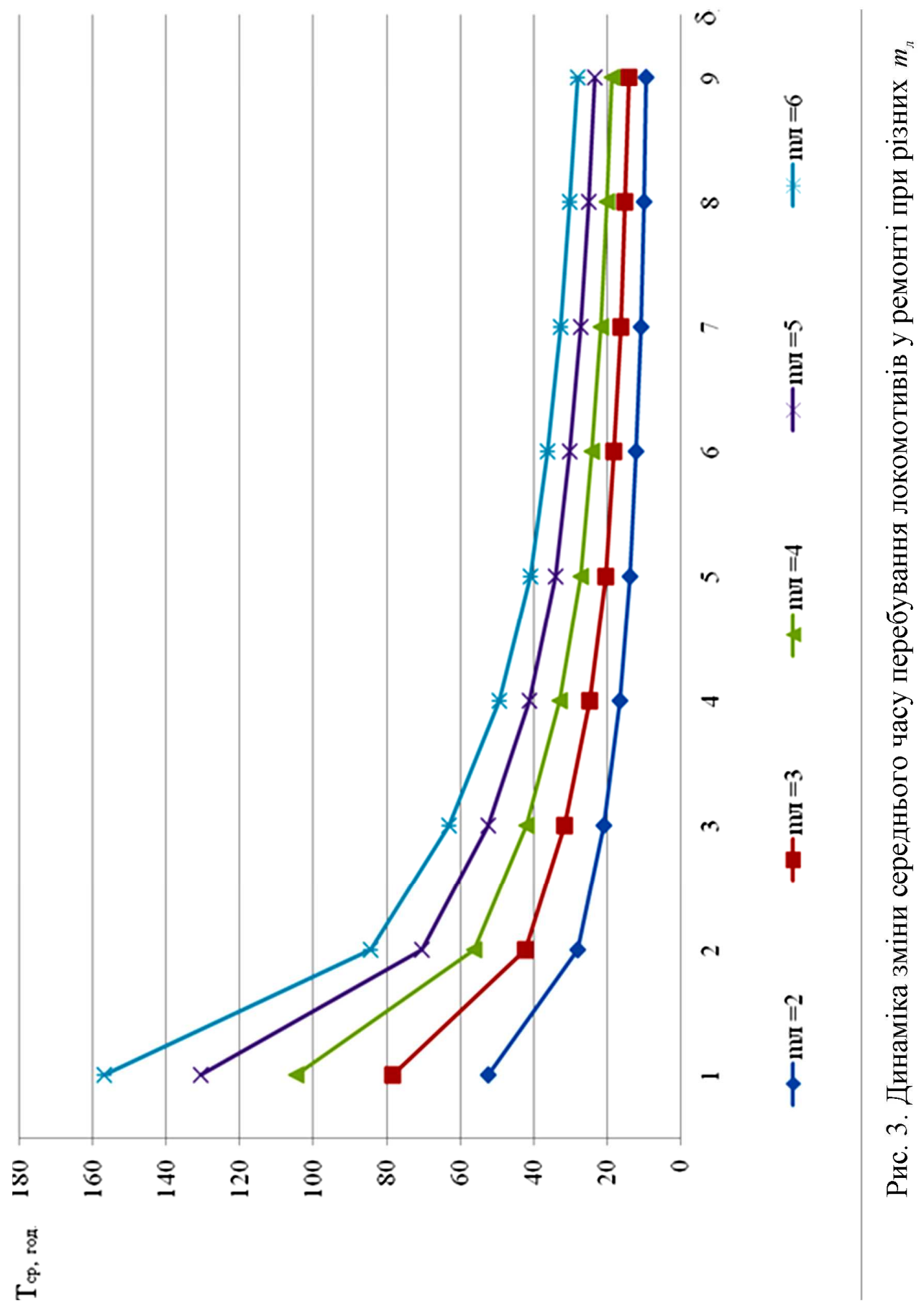


志

\begin{tabular}{|c|c|c|c|c|c|c|c|c|c|c|c|c|}
\hline$\infty^{2} 1 z$ & $\overrightarrow{\mathrm{i}}$ & $2=$ & $\overrightarrow{2}=$ & $\stackrel{Y}{\mathcal{Y}}$ & 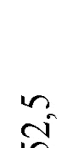 & 6 & 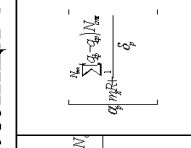 & 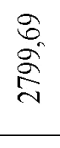 & $\begin{array}{l}\infty \\
\infty \\
\infty \\
\sim \\
\sim\end{array}$ & 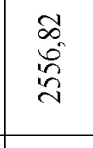 & $\begin{array}{l}\stackrel{2}{2} \\
\text { 䓌 } \\
\text { i }\end{array}$ & 疍 \\
\hline$u^{2}$ & ని & & ָे & in & 官 & क & 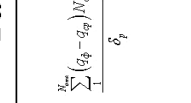 & $\stackrel{\circ}{i}$ & $\frac{7}{3}$ & 영 & $\cong$ & 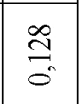 \\
\hline & \multirow{2}{*}{\multicolumn{6}{|c|}{ 오 }} & $z^{\frac{z^{3}}{\Xi}}$ & & & $N$ & & \\
\hline$z$ & & & & & & & 管 & $\begin{array}{l}\vec{b} \\
\stackrel{6}{6}\end{array}$ & 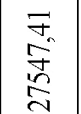 & 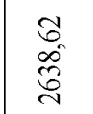 & 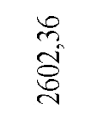 & 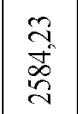 \\
\hline \multirow{2}{*}{$\begin{array}{c}0^{2} \mid z \\
v^{2}\end{array}$} & \multirow{2}{*}{ 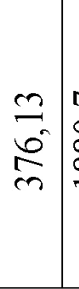 } & \multirow{2}{*}{$\begin{array}{l}10 \\
\infty \\
\infty \\
\infty \\
0\end{array}$} & \multirow{2}{*}{$\frac{3}{2}=$} & \multirow{2}{*}{ 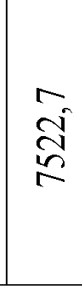 } & \multirow{2}{*}{$\frac{3}{8}$} & \multirow{2}{*}{ 志 } & 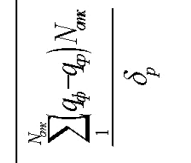 & $\stackrel{2}{\varrho}$ & $\underset{\substack{+i}}{i}$ & $\stackrel{\Omega}{\sigma}$ & $\begin{array}{l}\infty \\
\infty \\
0 \\
0 \\
0\end{array}$ & $\begin{array}{l}0 \\
\stackrel{n}{n} \\
0\end{array}$ \\
\hline & & & & & & & $z^{\frac{y^{5}}{\Xi}}$ & & & $m$ & & \\
\hline \multirow{2}{*}{$z$} & \multirow{2}{*}{\multicolumn{6}{|c|}{$n$}} & & 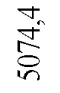 & $\begin{array}{l}\stackrel{n}{\circ} \\
\infty \\
\stackrel{8}{b}\end{array}$ & 溇 & 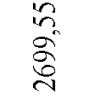 & 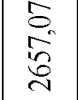 \\
\hline & & & & & & & $\stackrel{2}{\approx}$ & & & & & \\
\hline \multirow{3}{*}{$\left|\begin{array}{c}0^{2} \mid z \\
0^{2}\end{array}\right|$} & \multirow{3}{*}{ 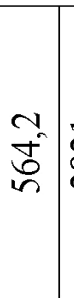 } & \multirow{3}{*}{$\begin{array}{l}\vec{\infty} \\
\text { స }\end{array}$} & & \multirow{3}{*}{$\stackrel{\Xi}{\Xi}$} & \multirow{3}{*}{ 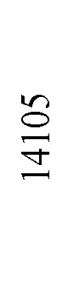 } & \multirow{3}{*}{ 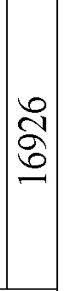 } & $\frac{a}{5-5}$ & $\stackrel{\sim}{\sim}$ & $\underset{c}{\infty}$ & $\stackrel{i n}{i}$ & $\stackrel{b_{0}}{-}$ & ב \\
\hline & & & & & & & 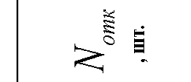 & & & F & & \\
\hline & & & & & & & & 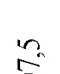 & $\infty$ & $\vec{b}$ & $\infty$ & $\dddot{7}$ \\
\hline$z$ & \multicolumn{6}{|c|}{ 으 } & 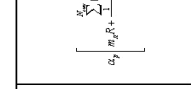 & $\bar{F}$ & 迹 & 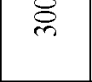 & 㞼 & $\stackrel{2}{2}$ \\
\hline \multirow[t]{2}{*}{$\begin{array}{c}0^{2} \mid z \\
u^{2}\end{array}$} & \multirow[t]{2}{*}{$\begin{array}{l}\underset{+}{\infty} \\
\stackrel{\infty}{\Xi} \\
=\end{array}$} & \multirow[t]{2}{*}{ 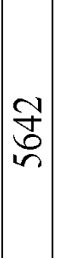 } & \multirow[t]{2}{*}{ 条 } & \multirow[t]{2}{*}{ 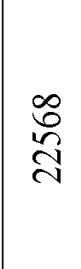 } & \multirow[t]{2}{*}{ 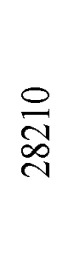 } & \multirow[t]{2}{*}{$\left|\begin{array}{l}N \\
\infty \\
\infty \\
\infty \\
m\end{array}\right|$} & 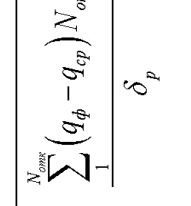 & $\begin{array}{l}2 \\
2 \\
2 \\
\sigma\end{array}$ & 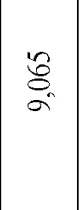 & 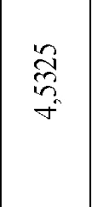 & త్ర & î \\
\hline & & & & & & & $\infty^{2} \cdot \bar{g}^{2}$ & - & in & 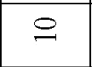 & $\cong$ & $\stackrel{\sim}{1}$ \\
\hline & \multirow{3}{*}{-} & & & \multirow{3}{*}{ 요 } & & & $z^{\text {埼主 }}$ & & & in & & \\
\hline \multirow[t]{2}{*}{$\infty^{2}$} & & \multirow[t]{2}{*}{$n$} & \multirow[t]{2}{*}{$\because$} & & $a$ & 요 & 용- & & & $\begin{array}{l}2 \\
\infty \\
\infty\end{array}$ & & \\
\hline & & & & & & & $\approx$ & & & 0 & & \\
\hline$>$ & & & & $n$ & & & $\equiv$ & & & t & & \\
\hline & & & & & & & $\sigma^{2}$ & & & 営 & & \\
\hline$v^{2}$ & & & & $\begin{array}{l}\text { fै } \\
\text { in }\end{array}$ & & & 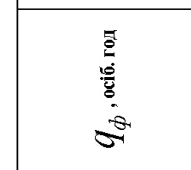 & $\begin{array}{l}6 \\
\infty \\
\infty\end{array}$ & 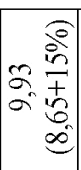 & 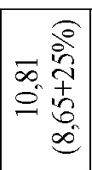 & 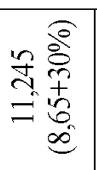 & 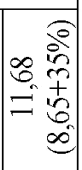 \\
\hline
\end{tabular}



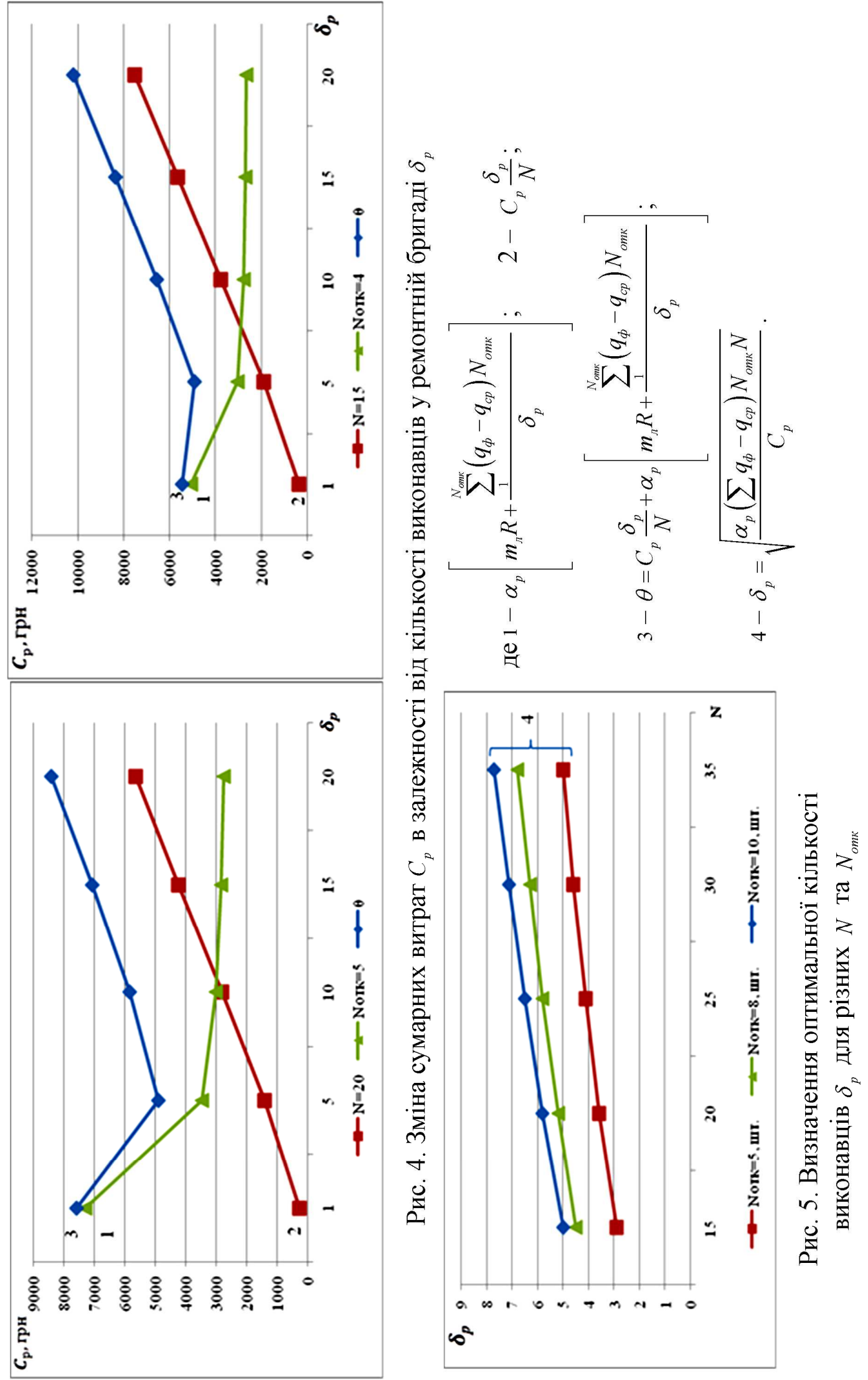
Перевіримо наведені графічні результати, продиференціювавши функцію $\theta$ і прирівнявши іiі до нуля. Тоді отримаємо такий вираз $\delta_{p}=\sqrt{\frac{\alpha_{p}\left(\sum q_{\phi}-q_{c p}\right) N_{\text {oтк }} N}{C_{p}}} \cdot$ Відповідно до рис. 4 а, б ці значення складають $\delta_{p}=\left(N=20, N_{\text {отк }}=5\right)=5, \quad \delta_{p}=\left(N=15, N_{\text {отк }}=4\right)=5$. Для зручного подання щодо вибору кількості $\delta_{p}$ на рис. 5 наведені значення $\delta_{p} \neq f\left(N, N_{\text {отк }}\right)$.

\section{Висновки 3 дослідження і перспективи подальшого розвиток у даному напрямку}

1. Створення резервів ремонтних бригад підвищує ймовірність виконання заявок на обслуговування в більшому діапазоні інтенсивності надходження заявок. Так, при $K=7, \delta=5$ зменшення роботи в діапазоні $\Delta \lambda=0,25 \div 2 \quad$ складає $\quad \Delta P_{\text {обс }}=0,1, \quad$ а $\quad$ при $K=7, \delta=2$ в цьому ж діапазоні $\Delta P_{\text {обс }}=0,5$ або вдвічі погіршується $P_{\text {обс }}$

2. Середній час простою в ТО, ПР в залежності від $(R+t)$ має тенденцію зменшення, причому незалежно від $m_{л}$ наступає період, коли $T_{c p}$ майже не змінюється, що пояснюється дуже повільною зміною $t_{3}$. Разом 3 цим, більш значний $m_{л}$ стабілізація починається раніше.

3. Оптимальне значення $C_{p}$ досягається в залежності від значень $N, \Delta t_{i}, m_{\pi}, R, \delta_{p}$. Змінюючи ці значення, прийнявши за аргумент $\delta_{p}$, визначаються оптимальні значення сумарних витрат на ремонт 3 оптимальною кількістю виконавців у ремонтній бригаді. Таким чином можна формувати і декілька ремонтних бригад, які складаються 3 необхідної кількості виконавців.

\section{Список використаних джерел}

1. Розпорядження Кабінету Міністрів України N 979p від 31 грудня 2004 року. URL: http://zakon3.rada.gov.ua/laws/show/979-2004$\% \mathrm{D} 1 \% 80$

2. G. Dwelk, D. Habelmann. Eisenbahntechnische Rundschau. 2005. № 9. P. 519 - 525.

3. S. Baumann, H-W. Kebler. Glasers Annalen, 2004, Tagungsband SFT, Graz.
4. Фалендиш А. П., Крашенінін О. С., Шапатіна О. О., Одегов М. М. Концепція розвитку i реструктуризації локомотивних депо. Збірник наукових праць ДонІЗТ. 2011. Вип. 27. С. 133-136.

5. Фалендиш А. П., Сумцов А. Л., Білецький Ю. В. Модель оптимізації системи технічного обслуговування та ремонту локомотивів. Вісник Східноукраӥнського національного університету імені Володимира Даля. 2013. Вип. 207 (2). С. 4549.

6. Иванова Н. Г. Применение методики расчета стоимости жизненного цикла при оценке эффективности инноваций на железнодорожном транспорте Локомотив. 2007. № 8. С. 12-15.

7. Тартаковский Э. Д., Грищенко С. Г., Калабухин Ю. Е., Фалендыш А. П. Методы оценки жизненного цикла тягового подвижного состава железных дорог: монография. Луганск : Ноулидж. 2011. 174 c.

8. Tartakovsky E., Ustenko O., Puzyr V., Datsun Y. System approach to the organization of locomotive maintenance on Ukraine railways. Studies in Systems, Decision and Control. Ukrainian state university of railway transport. Kharkiv, 2017. № 87. Р. 217-236.

9. Хинчин А.Я. Математические методы теории массового обслуживания. Москва : Изд. АН СССР, 1995. $123 \mathrm{c}$.

10. Вентцель Е. С. Теория вероятностей. Москва : Наука, 1969. 564 с.

11. Гнеденко Б. В., Ханчин А. Я. Элементарное введение в теорию вероятности. Москва: Наука, $1967.406 \mathrm{c}$.

12. Алдохин И. П. Теория массового обслуживания в промышленности. Москва: Экономика, 1970. $207 \mathrm{c}$.

13. Розенберг В. Я., Прохоров А. И. Что такое теория массового обслуживания. Москва : Советское радио, 1965. $256 \mathrm{c}$.

14. Четыркин Е. М. Теория массового обслуживания и ёё применение в экономике. Москва : Статистика, $1971.103 \mathrm{c}$.

15. Кузнецов Е. С., Сорокин В. А. Исследование работы поточных линий технического обслуживания автомобилей. Москва : Транспорт, 1966. 83 c.

16. Krasheninin O., Klymenko O., Ponomarenko O., Yakovlev S. Justification of statutory service life extension of locomotives on the basis of theory of aging. International Journal of Engineering \& Technology. 2018. № 7 (43). P. 174-178. 
Яковлев С. С. Обеспечение технологической надёжности работы подразделений ремонтного хозяйства локомотивного депо.

Аннотация. Рассмотрены вопросы обеспечения технологической надежности работы ремонтных подразделений локомотивного депо по ремонту скоростного подвижного состава по критерию оптимального количества исполнителей в ремонтных бригадах, что обеспечит выполнение ТО, ТР для приписного парка локомотивов, в том числе из других локомотивных депо. Определены зависимости изменения вероятности обслуживания заявки на ремонт от интенсивности потока заявок на ремонт, а также оптимальное количество исполнителей в ремонтных бригадах.

Ключевые слова: вероятность обслуживания, параметр потока заявок на ремонт.

Yakovlev S. Providing technological reliability of the working of locomotive depot reports subdivisions.

Abstract. Considered the issues of ensuring technological reliability of work of repair subdivisions of the locomotive depot specialized in repair of high-speed rolling stock, by the criterion of the optimal number of specialists in repair team, that will ensuring maintenance and ongoing repairs for the current fleet of locomotives, including from other locomotive depots.

It is determined that the efficiency of modern repair production is affected by the instability of the volume of work performed. This has a negative impact on both the use of labor resources and the quality of repair work. From a mathematical point of view, repair service can be considered as a queuing system with a regulated time for the application (on repair of locomotive section, technical nodes, parts) in a system with orderly maintenance, the input of which receives the simplest stream of applications A with intensity $\lambda$, and at the exit of the system two streams are formed: B - applications that are serviced with intensity $\lambda_{0}$, and $\mathrm{C}$ - applications that are not serviced with intensity $\lambda_{\mathrm{H}}$.

At fluctuating the flow of repair requests and repair time, there are two ways to improve the efficiency of repair units: mutual assistance, which is possible if specialists are interchangeability, or the creation of a reserve group from several specialists. Based on this, the calculations of the change in the number of specialists performing maintenance and ongoing repairs were carried out, depending on the intensity of the inbound stream $\lambda$, at the same value of the number of applications K. From the calculations it is determined that the most appropriate is the creation of a reserve group. By varying the number of specialists in the team, you can determine the range of the highest probability of servicing an application (completion of repairs). The optimal number of specialists of the reserve group can be defined by minimizing the costs of repairing one locomotive section, based on the objective function of assessing the technological reliability of the system of repair. At different number of specialists $\delta_{\mathrm{p}}$, it is possible to determine the required number of specialists in the reserve group, which will ensure minimal repair costs.

It is established that with increasing number of specialists $\delta_{\mathrm{p}}$ it is possible to significantly reduce downtime in repair.

Creating reserves for repair subdivisions increases the likelihood of executing applications on service in a greater range intensity of applications entrance.

Key words: service probability, repair claims flow parameter.

Надійшла 30.06.2019 p.

Яковлев Сергій Сергійович, аспірант кафедри експлуатації та ремонту рухомого складу, Український державний університет залізничного транспорту, Харків, Украӥна. E-mail: errs1@таil.иа , ORCID ID: https://orcid.org/0000-0002-8578-4566

Yakovlev Sergey Sergeevich, post-graduate student of the Department of Operation and Repair of Rolling Stock, Ukrainian State University of Railway Transport, Kharkiv, Ukraine. E-mail: errs1@mail.ua ORCID ID: https://orcid.org/0000-0002-8578-4566 